\title{
Breast Cancer pT4a TNM Finding v6 and v7
}

National Cancer Institute

\section{Source}

National Cancer Institute. Breast Cancer pT4a TNM Finding v6 and v7. NCI Thesaurus.

Code $C 48986$.

Breast cancer with extension to the chest wall, not including the pectoralis muscle. (from AJCC 6th and 7th Eds.) 